\title{
Evaluation of the Cytotoxic Effects of CAM Therapies: An In Vitro Study in Normal Kidney Cell Lines
}

\author{
Shagun Arora, Chanderdeep Tandon, and Simran Tandon \\ Department of Biotechnology and Bioinformatics, Jaypee University of Information Technology, Waknaghat Solan 173234, India \\ Correspondence should be addressed to Chanderdeep Tandon; chanderdeep.tandon@juit.ac.in
}

Received 26 August 2013; Accepted 7 November 2013; Published 3 February 2014

Academic Editors: D. Geetha, F. Thaiss, and Y. Uchiyama-Tanaka

Copyright (c) 2014 Shagun Arora et al. This is an open access article distributed under the Creative Commons Attribution License, which permits unrestricted use, distribution, and reproduction in any medium, provided the original work is properly cited.

\begin{abstract}
The purpose of this current study was to justify the incorporation of complementary and alternate medicine (CAM) in current cancer treatments. The major drawback of anticancer drugs is their nonselective killing, which ultimately leads to attrition of normal cells. Keeping this as the foundation of our study, we made an effort to compare the cytotoxicity associated with a known chemotherapeutic drug 5-Fluorouracil (5-FU), with certain CAM therapies previously reported to have anticancer activity. The parameters chosen for the study were based on antiproliferative and cytotoxic effects on normal, kidney epithelial cells (NRK-52E). The MTT assay, colony formation assay, DNA fragmentation, and differential staining using AO/EB, following treatment with either 5-FU or CAM therapies, were performed. The CAM therapies under study were various extracts of wheatgrass, roots of Achyranthes aspera (AA), mushroom extracts (Pleurotus ostreatus, Macrolepiota procera, and Auricularia polytricha), and a homeopathic drug, Ruta graveolens (Ruta). The results showed that treatment of normal cells with the CAM therapies led to minimum cell damage in comparison to 5-FU. This evidence-based study will lead to greater acceptance of alternative therapies against cancer.
\end{abstract}

\section{Introduction}

Kidney cancer is ranked as the 11th most common cancer in both sexes and accounts for almost $2 \%$ of all cancers, with an incidence rate of 169,155 and mortality rate of 466,631 per 100,000 people worldwide [1]. 5-Fluorouracil (5-FU) is a well-established chemotherapeutic drug used against various cancers [2,3], which kills the cancer cell by interfering with their growth. However, this killing is nonselective and not only eliminates the fast-growing cancer cells but also other fast-growing cells in the body, including hair and blood cells, owing to which it exhibits severe toxicity and undesirable side effects [4]. 5-FU has been shown to be associated with renal toxicity $[5,6]$. This puts the patient at added risk when undergoing chemotherapy. The burden of renal toxicity therefore limits the dose and duration for which the patient can be exposed to the drug.

A variety of therapeutic or preventive health care practices followed worldwide, having limited scientific literature for their effectiveness, are referred to as complementary and alternative medicines (CAM). These include homeopathy, naturopathy, Chinese traditional medicine, and Indian herbal medicine [7]. Their popularity stems from their easy availability and cost effectiveness and the fact that they have been used for centuries. Over the years, several surveys have shown the potential role of various CAM therapies over conventional therapies in cancer treatment [8-10]. According to the $\mathrm{WHO}$, around $80 \%$ of the world population relies upon CAM therapies for their primary health care [11]. A survey, conducted by Indian Council of Medical Research, revealed that $38 \%$ of cancer patients opted for alternative treatments before using allopathic medicines $[12,13]$. The objective of our study stems from the belief that although several chemotherapeutic drugs are available in the market against cancer, they fail to discriminate between the normal healthy cells and malicious cancer cells, thereby leading to the various side effects. Therefore, CAMs, which have been around for centuries and whose therapeutic potential is known, could better serve to protect the normal cells over conventional 
treatments, while at the same time killing or retarding the cancer cells.

We tested the effect of several well-documented sources of CAM therapies (Triticum aestivum (wheatgrass), Achyranthes aspera roots, Mushroom species, Pleurotus ostreatus, Macrolepiota procera and Auricularia polytricha, and homeopathic drug, Ruta graveolens) by exploring various parameters such as cytotoxicity, morphological alterations, antiproliferative and apoptotic effects and compared them with 5-FU on normal kidney epithelial cells (NRK-52E) [14-17].

The young grass of Triticum aestivum is commonly known as wheatgrass. Wheatgrass extract has been shown to possess antioxidant and anticancer activity and wound healing property, inhibits oxidative damage, and strengthens the immune system by inhibiting the metabolic activation of carcinogens [18-23]. Achyranthes aspera (AA) is a popular folk remedy in traditional system of medicine throughout the tropical Asian countries. This plant is reported to be used as immunostimulant, antioxidant, diuretic, antipyretic, hepatoprotective, antiproliferative, anticancerous, cytotoxic, and antiinflammatory agent and also used for treatment of renal dropsy and ulcers $[24,25]$.

For thousands of years, various species of mushrooms have been used as an integral part of traditional Chinese medicine and have accordingly been classified as medicinal mushrooms. Medicinal properties of mushroom are well documented and include anticancer, antioxidant, antiinflammatory, antiulcers, wound healing, and activation of immune response by activating helper $\mathrm{T}$ cells, cytotoxic $\mathrm{T}$ cells, natural killer cells, and macrophages [26, 27].

Ruta graveolens L. commonly known as Rue is an herbaceous perennial, originally native to the Mediterranean region. The therapeutic uses of Ruta include the treatment of inflammatory conditions, activation of T cells, prevention of ulcers formation, and inhibition of cancer cell proliferation $[28,29]$.

Studies carried out by our group have shown that these CAM therapies are highly effective against cancer cell lines. We have earlier shown that the extracts of wheatgrass effectively kill breast cancer MCF7 cells [30]. The effect of Pleurotus ostreatus, Macrolepiota procera, and Auricularia polytricha extracts were also checked on breast (MCF-7), colon (COLO-205), and kidney (ACHN) cancer cell lines in our lab. and studies revealed their cytotoxic, antiproliferative, and apoptotic effects against cancer cells [31]. The evidence for the antiproliferative effects of Ruta on cancer cells was also reported recently by Arora et al. [32]. In addition, we have seen that the extract of Achyranthes aspera roots has the ability to induce apoptosis in cancer cells.

Although the therapeutic activities of all these CAM therapies are reported to possess anticancer activity, the question still remains whether these therapies spare healthy cells in comparison to known chemotherapeutic drug, that is, 5-FU. Our current study has therefore tried to systematically explore this aspect of CAM therapies and document for the first time its "no-side effect policy," through scientific fact and not belief.

\section{Material and Methods}

2.1. Collection of Plant Material. The seeds of Triticum aestivum were obtained from HAU (Chaudhary Charan Singh University, Hisar). The dried roots of Achyranthes aspera were procured from Natural Remedies Pvt. Ltd. at Bangalore, India, while the three species of mushroom (i.e., Auricularia polytricha, Macrolepiota procera, and Pleurotus ostreatus) were procured from Directorate of Mushroom Research, Solan, Himachal Pradesh, India. The ultradiluted (10 M, 1 M, 200 C, 30 C) potencies and mother tincture (MT) of Ruta graveolens were procured from Dr. Reckeweg \& Co, Germany.

2.2. Cell Line. NRK-52E cell line was used as an in vitro model in our study and was obtained from NCCS Pune, India. The cells were cultured in Dulbecco's modified Eagle medium (DMEM) supplemented with 1\% (v/v) PenicillinStreptomycin obtained from Gibco and 10\% (v/v) FBS obtained from Sigma-Aldrich. The cells were maintained at $37^{\circ} \mathrm{C}$ in a $5 \% \mathrm{CO}_{2}$ incubator. Cells at exponential stage were used for experimentation and medium was changed every 2-3 days.

\subsection{Preparation of Plant Extracts}

2.3.1. Preparation of Wheatgrass Extracts. The seeds were soaked overnight. Next day, the sprouted seeds were sowed in trays containing fertile soil. The trays were monitored daily and watered as per the need. The desired length of the wheatgrass to be used in our study was of 6-7 inches, as a particular study revealed that maximum antioxidant activity was observed in a wheatgrass of this length [33]. Successive extraction procedure was followed with an increasing order of polarity of solvent used such as hexane, chloroform, methanol, and water in a Soxhlet apparatus; subsequently the following extracts were obtained: hexane wheatgrass extract (HWE), chloroform wheatgrass extract (CWE), methanol, wheatgrass extract (MWE), and aqueous wheatgrass extract (AWE). The supernatants obtained were filtered and were further concentrated in Rotary Evaporator or lyophilized as per need.

2.3.2. Preparation of $A A$ Extracts. $10 \%(\mathrm{w} / \mathrm{v})$ aqueous and ethanolic extract was prepared by dissolving 10 grams of dried roots of AA in $100 \mathrm{~mL}$ of each solvent overnight at room temperature; next day the supernatants were filtered by Whatman filter number 2. For ethanolic extract, the filtrate obtained was further concentrated in Rotary Evaporator (at $50^{\circ}-60^{\circ} \mathrm{C}$ ) under reduced pressure leaving a dark brown residue and was transferred to a petri dish and kept in an oven $\left(50^{\circ} \mathrm{C}\right)$ until the solvent was completely evaporated and termed as EAA-ethanolic root extract of Achyranthes aspera. While for aqueous extract the filtrate was lyophilized and termed as AAA-aqueous root extract of Achyranthes aspera.

2.3.3. Preparation of Mushroom Extracts. The dried mushrooms were subjected to coarse grinding in a pestle and mortar, followed by grinding in a mixer-grinder until a fine 
powder was achieved. 10\% (w/v) aqueous extract of all three species was prepared by dissolving 10 grams of the powdered mushroom sample in $100 \mathrm{~mL}$ of water, followed by extraction using Soxhlet apparatus. This process was carried out for 2-3 days until the appearance of a coloured solution and all the extracts were then lyophilized in a lyophilizer to obtain the dry powdered extract, namely, Pleurotus ostreatus aqueous extract (PAE), Auricularia polytricha aqueous extract (AAE) and Macrolepiota procera aqueous extract (MAE).

All the extracts were stored at $-20^{\circ} \mathrm{C}$ until further use. The extracts which were added to the cells in culture were solubilised in cell culture grade DMSO and filtered through a 0.22 micron filter. The further dilution to obtain a range of concentrations was done using DMEM.

2.3.4. Homeopathic Drug. The prepared potencies of Ruta graveolens used in our study were $10 \mathrm{M}, 1 \mathrm{M}, 200 \mathrm{C}, 30 \mathrm{C}$, and mother tincture (MT).

2.4. Cytotoxicity Assessment by MTT Assay. The cytotoxic activity was measured using MTT (3-(4,5 dimethylthiazol2-yl)-2,5-diphenyltetrazolium bromide) assay [34]. Briefly, $10^{4}$ cells/well were seeded in 96-well microplates. Cells were treated with various concentrations $(20-120 \mu \mathrm{g} / \mathrm{mL})$ of $\mathrm{HWE}$, CWE, MWE, AWE, PAE, MAE, AAE, EAA, and AAA and all potencies of Ruta including $10 \mathrm{M}, 1 \mathrm{M}, 200 \mathrm{C}, 30 \mathrm{C}$, MT and $5-\mathrm{FU}(1-5 \mu \mathrm{g} / \mathrm{mL})$ for 48 hours. At the end of incubation period, the medium was removed and $15 \mu \mathrm{L}$ MTT $(5 \mathrm{mg} / \mathrm{mL})$ was added to each well, followed by an incubation period for a further 4 hours at $37^{\circ} \mathrm{C}$. Later, $150 \mu \mathrm{L}$ of DMSO was added to each well for solubilisation of the formazan products. Absorbance was taken at $570 \mathrm{~nm}$ using a Bio-Rad microplate reader. The percent cell cytoxicity was calculated by means of the formula:

$$
\begin{aligned}
& \% \text { Cytotoxicity } \\
& =\frac{\text { O.D of control sample }- \text { O.D of treated sample }}{\text { O.D of control sample }} \\
& \times 100 \text {. }
\end{aligned}
$$

2.5. Assessment of Morphological Alterations. $10^{5}$ cells $/ \mathrm{mL}$ were seeded in a 12 -well plate and, upon reaching a confluency of $80 \%$, were subjected to various treatments for a period of 48 hours, with $\mathrm{IC}_{50}$ concentrations of $\mathrm{HWE}, \mathrm{CWE}$, MWE, AWE, PAE, MAE, AAE, EAA, and AAA and 5-FU. This $\mathrm{IC}_{50}$ value refers to the concentration of the extract which results in $50 \%$ killing on the cells upon treatment. After 48 hours, cells were visualized to assess the changes in cell morphology and cell density in presence or absence of various CAM therapies or 5-FU and photographed under a phase contrast microscope at 100x magnification using Nikon eclipse Ti fluorescence microscope [34].

2.6. Antiproliferation Assay. Antiproliferative activity was investigated by performing colony forming assay (CFU) [35]; briefly 5000 cells were cultured in a 6-well plate and incubated for 48 hours with $\mathrm{IC}_{50}$ value of $\mathrm{HWE}, \mathrm{CWE}, \mathrm{MWE}$, AWE, PAE, MAE, AAE, EAA, AAA and 5-FU. Ruta was added at a concentration of $5 \mu \mathrm{L} / \mathrm{mL}$ for 48 hours. After the treatment period, old medium was replaced with fresh medium (minus any CAM or 5-FU) and incubated at $37^{\circ} \mathrm{C}$ for a further 10 days. Cells were then fixed with $4 \%$ paraformaldehyde for 30 minutes at $4^{\circ} \mathrm{C}$ and then stained with $0.5 \%$ of crystal violet for 30 minutes and counted using a colony counter.

\subsection{Apoptosis Assay}

2.7.1. Acridine Orange/Ethidium Bromide Staining. Nuclear morphology of the cells was visualized by fluorescence microscopy after staining with acridine orange/ethidium bromide $(\mathrm{AO} / \mathrm{EB})$ double dye. The cells $\left(10^{5}\right.$ cells $\left./ \mathrm{mL}\right)$ were cultured in a 12-well plate, followed by treatment with its $\mathrm{IC}_{50}$ value of $\mathrm{HWE}, \mathrm{CWE}, \mathrm{MWE}$, AWE, PAE, MAE, AAE, EAA, AAA and 5-FU and $30 \mathrm{C}$ and MT of Ruta $(5 \mu \mathrm{L} / \mathrm{mL})$ for 48 hours. Later, both adherent and cells in suspension were collected and centrifuged at $130 \times \mathrm{g}$ for 5 minutes. The pellet was resuspended in a solution of $25 \mu \mathrm{L}$ $\mathrm{PBS}$ and $2 \mu \mathrm{L}$ AO/EB dye $(100 \mu \mathrm{g} / \mathrm{mL})$. Slides were prepared and fluorescence was observed with the help of a Nikon eclipse $\mathrm{Ti}$ fluorescence microscope at 200x magnification [36].

2.7.2. DNA Fragmentation Assay. $2 \times 10^{6}$ cells were seeded in $35 \mathrm{~mm}$ tissue culture dish and incubated for 24 hours until the $80 \%$ confluency was achieved. The cells were treated with $\mathrm{IC}_{50}$ value of $\mathrm{HWE}, \mathrm{CWE}, \mathrm{MWE}, \mathrm{AWE}, \mathrm{PAE}, \mathrm{MAE}$, AAE, EAA, AAA and 5-FU and $30 \mathrm{C}$ and $\mathrm{MT}$ of Ruta $(5 \mu \mathrm{L} / \mathrm{mL})$ for 48 hours. After incubation period, both the cells in suspension and attached cells were pooled together in $1.5 \mathrm{~mL}$ eppendorf vial and centrifuged at $200 \mathrm{~g}$ for 10 minutes at $4^{\circ} \mathrm{C}$. The pellet obtained was resuspended in $0.5 \mathrm{~mL}$ TTE $(10 \mathrm{Mm}$ Tris $+1 \mathrm{mM}$ EDTA $+0.2 \%$ Triton $\times 100$ ) followed by vigorous vortexing and centrifuged at $20,000 \times \mathrm{g}$ for 10 minutes at $4^{\circ} \mathrm{C}$ and the supernatant obtained upon centrifugation was collected in a new vial. To $0.5 \mathrm{~mL}$ supernatant, $0.1 \mathrm{~mL}$ ice-cold $5 \mathrm{M} \mathrm{NaCl}$ and $0.7 \mathrm{~mL}$ ice-cold isopropanol were added and vortexed vigorously and kept at $-20^{\circ} \mathrm{C}$ overnight to precipitate the DNA. Next day, centrifugation at $20,000 \times \mathrm{g}$ for 10 minutes at $4^{\circ} \mathrm{C}$ was done. The pellet obtained was washed with $0.5-0.7 \mathrm{~mL}$ ice-cold $70 \%$ ethanol and centrifuged at $16,100 \times \mathrm{g}$ for $10 \mathrm{~min}$ at $4^{\circ} \mathrm{C}$. Finally, the pellet was dissolved in $50 \mu \mathrm{L}$ TE (Tris- EDTA). The DNA was run on a $1 \%$ agarose gel containing ethidium bromide and visualised using a Bio-Rad Gel-Doc system [37].

2.8. Statistical Analysis. The results are presented as means \pm $\mathrm{SD}$ of three independent experiments. Statistical differences among means were determined by one-way ANOVA. Differences were considered significant at $P<0.05$. The $\mathrm{IC}_{50}$ values were calculated using GraphPad Prism 5.0 (GraphPad Software Inc., San Diego, CA). Every experiment included a set of negative controls (untreated cultures). 


\section{Results}

3.1. Evaluation of Cytotoxicity by Various CAM Therapies and 5-FU on NRK-52E Cells. Normal kidney epithelial cells, NRK-52E cells, were treated with the various CAM therapies as well as 5-FU for 48 hours, to check for their cytotoxic effect. The outcome of this study revealed that, in contrast to the known chemotherapeutic drug (5-FU), the CAM therapies were significantly less toxic to normal cells. 5FU, as indicated in Figure 1, showed remarkably stronger cytotoxic activity on the normal kidney cells with an $\mathrm{IC}_{50}$ value of $4.56 \pm 0.41 \mu \mathrm{g} / \mathrm{mL}$, which was significantly lower than that of the CAM extracts under study with a $\mathrm{IC}_{50}$ value of $318.92 \pm 0.13 \mu \mathrm{g} / \mathrm{mL}$ for HWE, $266.67 \pm 0.38 \mu \mathrm{g} / \mathrm{mL}$ for CWE, $356.09 \pm 0.26 \mu \mathrm{g} / \mathrm{mL}$ of MWE, $456.15 \pm 0.47 \mu \mathrm{g} / \mathrm{mL}$ of AWE, $395.35 \pm 0.67 \mu \mathrm{g} / \mathrm{mL}$ of EAA, $509.83 \pm 0.17 \mu \mathrm{g} / \mathrm{mL}$ of $\mathrm{AAA}, 853.40 \pm 0.51 \mu \mathrm{g} / \mathrm{mL}$ of PAE, $313.25 \pm 0.46 \mu \mathrm{g} / \mathrm{mL}$ of $\mathrm{AAE}$, and $279.12 \pm 0.34 \mu \mathrm{g} / \mathrm{mL}$ of MAE. The mother tincture (MT) of Ruta showed $19.53 \pm 0.25 \%$ killing on NRK-52E cells, so $\mathrm{IC}_{50}$ value of Ruta on NRK-52 E cells was not calculated as $50 \%$ cell killing does not lie within the range of the ultradiluted remedies (10 M-MT) used. Further experiments were therefore done using $30 \mathrm{C}$ and MT potencies. As is evident the $\mathrm{IC}_{50}$ values of the CAM therapies on the normal cells are very high, indicating their noncytotoxic nature.

3.2. Assessment of Morphological Variations of NRK-52E Cells. The $\mathrm{IC}_{50}$ values of all samples that is, HWE, CWE, MWE, AWE, PAE, MAE, AAE, EAA, AAA, $30 \mathrm{C}$, and MT potencies of Ruta, along with 5-FU, were then used for the treatment of NRK-52E cells, in a 12-well plate format, for 48 hours. Following this, the change in morphology and cell growth was evaluated and photographed as shown in Figure 2. The results revealed that the CAM therapies had hardly any growth retarding effect or any apparent effect on the morphology of the cells. In contrast the normal cells treated with 5-FU were severely affected and resulted in altered shape as well as a visible decrease in cell growth, as evidenced by clear patches seen in the wells of the plate.

3.3. Effect of CAM Source and 5-FU on NRK-52E Cell Proliferation. Colony formation assay was adopted in our study as a means to evaluate the long term effect on proliferation of NRK-52E, of the various CAM treatments, in comparison to 5-FU. After an initial treatment period of 48 hours, the cells were allowed to proliferate in absence of any treatment for a further 10 days, to check the ability of cells to resume the normal cell cycle leading to proliferation. In Figure 3, a significant decrease in cell proliferation was observed, when cells were treated with 5-FU and were allowed to proliferate for the next 10 days in absence of drug, while the effect of CAM therapies on NRK-52E cells was insignificant in comparison to 5 -FU.

\subsection{Apoptotic Effect on NRK-52E Cells}

3.4.1. Acridine Orange/Ethidium Bromide Dual Staining. In general, upon treatment with $\mathrm{AO} / \mathrm{EB}$ dyes, the viable cells

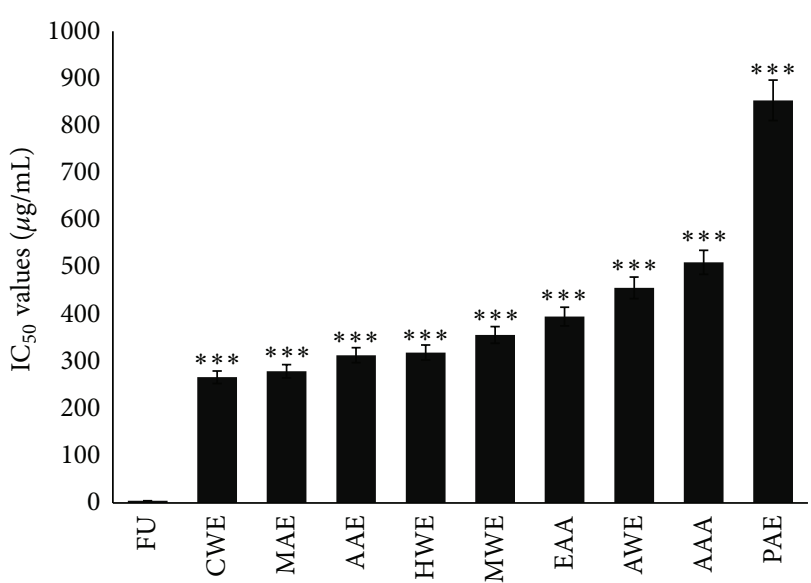

Figure 1: $\mathrm{IC}_{50}$ value of HWE, CWE, MWE, AWE, EAA, AAA, PAE, AAE, MAE, and 5-FU on NRK-52E cells measured by MTT assay after 48 hours of treatment. Data presented as mean \pm S.D $(n=3)$ and compared to $\mathrm{IC}_{50}$ value of 5 -FU. ${ }^{* * *} \mathrm{P}<0.001$.

show round and green nuclei, while early apoptotic cells have fragmented DNA with green colored nuclei and late apoptotic and necrotic cells show fragmented DNA with orange and red nuclei. From the data obtained from our study, shown in Figure 4, it was clear that CAM therapies showed intact DNA and round and green nuclei, whereas 5-FU showed fragmented DNA with green colored nuclei along with typical characteristics of apoptotic cells, including plasma membrane blebbing.

3.4.2. DNA Fragmentation Assay. The process of DNA fragmentation is a clear sign of activation of apoptosis, or programmed cell death, via intrinsic pathway, which is linked to the involvement of a specific enzyme, that is, caspase activated deoxyribonuclease (CAD). CAD, upon activation by a variety of carcinogens, leads to the cleavage of the intact DNA to produce ladder-like DNA fragments of specific size of 180-200 bp. As a biochemical hallmark of cell death via apoptosis, DNA fragmentation was used to determine the effect of CAM therapies versus 5-FU effect on cell death (if any) of normal kidney epithelial cells. As shown in Figure 5, the treatment of NRK-52E cells with CAM therapies showed intact DNA with no signs of DNA fragments or laddering, indicating no apoptotic effect of these sources of CAM on normal kidney cells in contrast to 5-FU.

\section{Discussion}

In this study, we have provided the first report on the noncytotoxic nature on normal kidney cells, of certain plant extracts, having anticancer properties.

Most chemotherapeutics treatments used for the eradication of cancer cells also kill a diverse range of normal cell types, leading to a broad range of adverse side effects including renal toxicity $[38,39]$. 5 -FU belongs to a class of chemotherapeutic drugs, which although being highly effective leads to a wide range of toxicity within multiple 


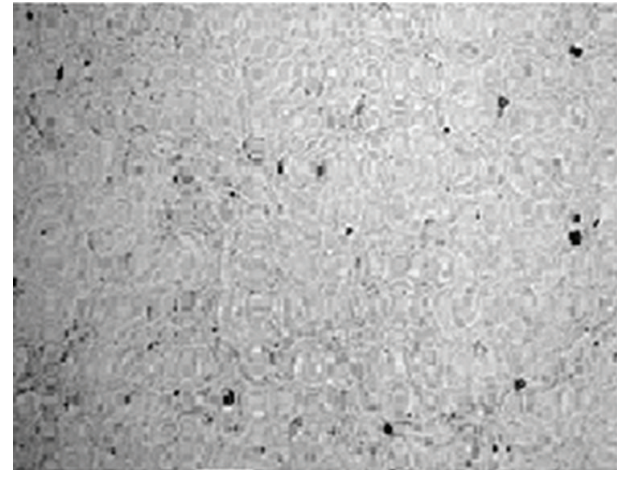

(A)

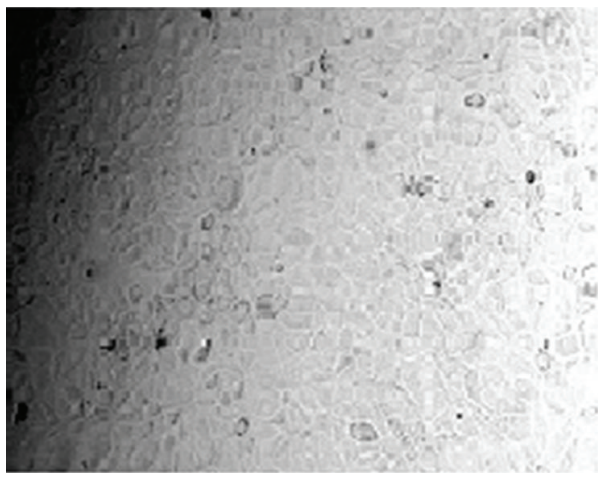

(C)

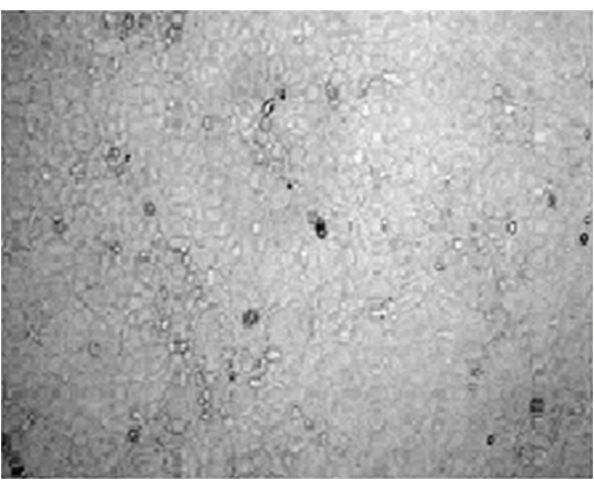

(E)

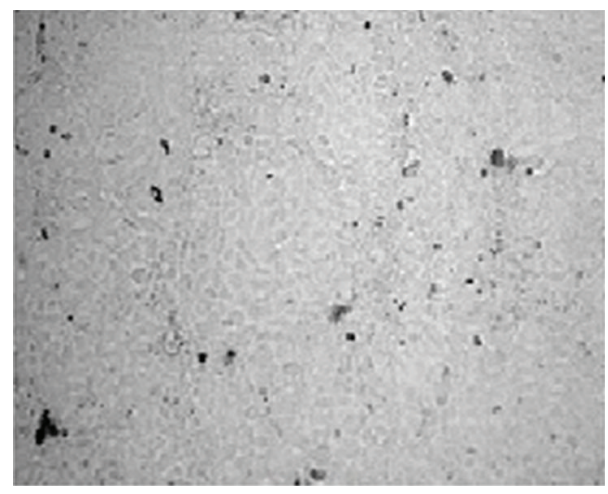

(G)

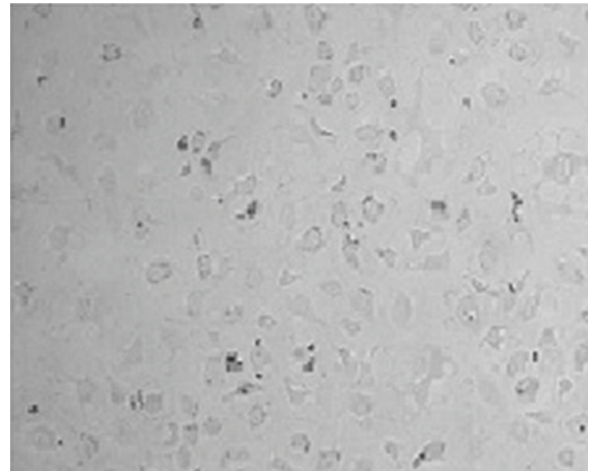

(B)

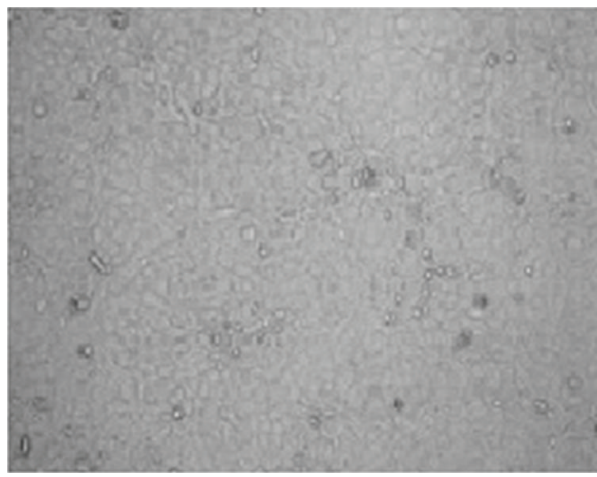

(D)

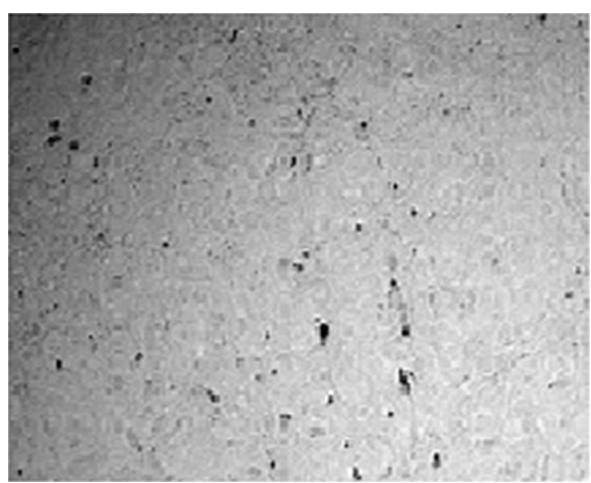

(F)

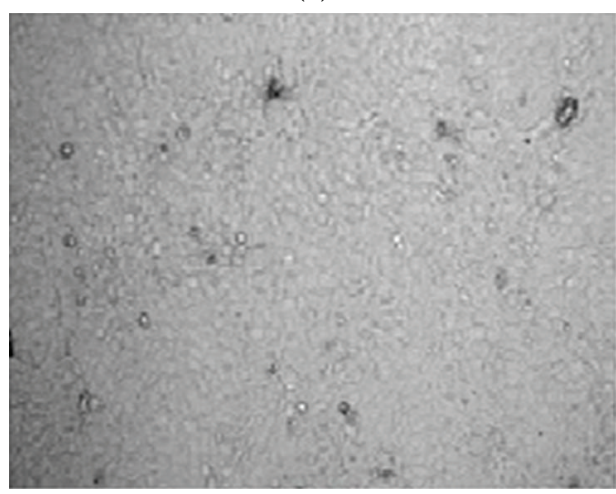

(H)

FIgURE 2: Continued. 


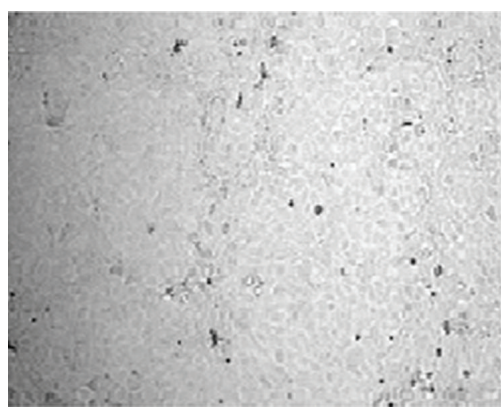

(I)

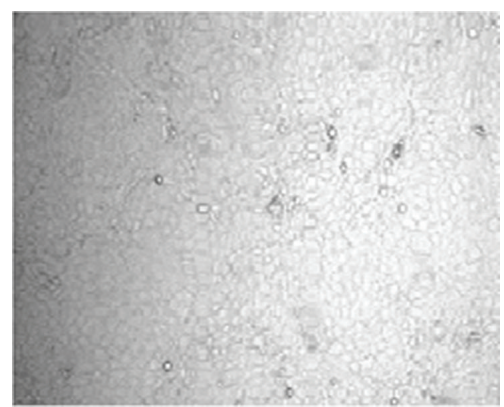

(J)

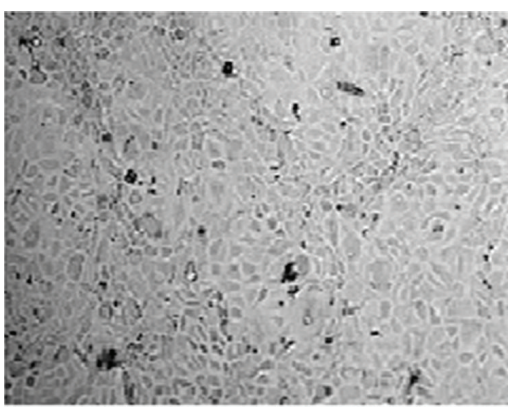

(K)

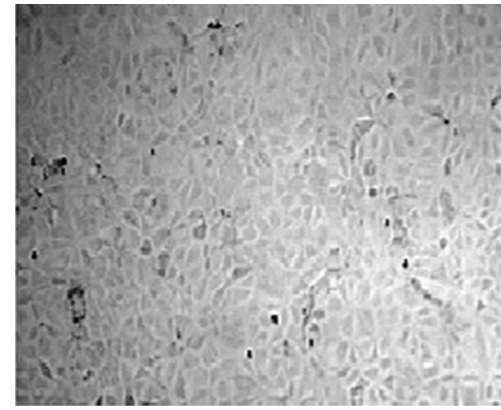

(L)

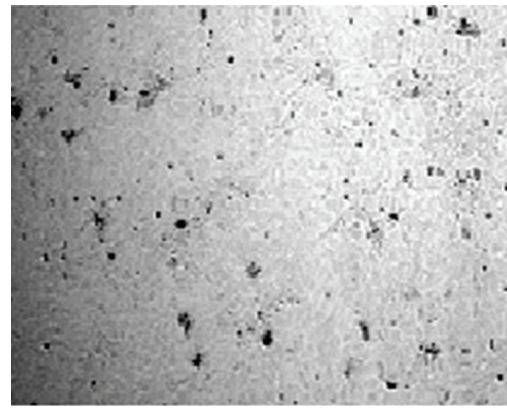

(M)

Figure 2: Effect of IC $_{50}$ (based on MTT assay) values of HWE, CWE, MWE, AWE, EAA, AAA, PAE, AAE, MAE, 30 C, and MT of Ruta and 5-FU on cell growth of NRK-52E cells after treatment period of 48 hours. (A) Control (untreated); (B) 5-FU; (C) HWE; (D) CWE; (E) MWE; (F) AWE; (G) EAA; (H) AAA; (I) PAE; (J) AAE; (K) MAE; (L) 30 C; (M) MT after 48 hours treatment (magnification at 100x).

organ systems, one of which is the kidney. A study reported that, on 5-FU administration, a significant increase in serum urea, creatinine, uric acid, cortisol, and potassium was observed, along with significant decrease in sodium and magnesium that leads to kidney injury. Increase in levels of malondialdehyde along with decreased levels of glutathione concentrations, after treatment with 5-FU, was also seen in renal tissues [5]. Similar results were observed in another study that showed 5-FU-induced nephrotoxicity in normal rats [6].

Although they induce severe cellular cytotoxicity and related side effects, many chemotherapeutic drugs continue to be used for the severe want of anticancer therapies with little or no toxicity to normal cells. Hence, there is an urgent need for new therapies that can offer hope. Alternative medicine is one such avenue which has been used worldwide since ancient times. However, owing to limited documented data that proves that CAM therapies have minimal or no toxic effect on normal cells, their use in conventional therapies has been restricted. We, therefore, decided to systematically evaluate the effect on normal kidney cells of proven CAM therapies, having antiproliferative and cytotoxic effect on cancer cells.

In our study four different sources of alternative therapies, with known anticancer properties, were evaluated; these included Triticum aestivum, Achyranthes aspera, certain medicinal mushrooms, and the homeopathic drug-Ruta [14-18]. They were individually tested on NRK-52E cells, which is a normal kidney epithelial cell line, to check whether these cells retain their healthy state upon treatment and compared the results with 5-FU.

The in vitro data from this study highlights the advantage of CAM therapies over 5-FU in terms of protective effect towards normal cells. Various parameters were assessed in our study, which included cell cytotoxicity by MTT assay, cell proliferation assay by colony formation assay, and apoptosis study by $\mathrm{AO} / \mathrm{EB}$ dual staining and DNA fragmentation assay. The $\mathrm{IC}_{50}$ values of these CAM sources on NRK-52E cells, when compared with $\mathrm{IC}_{50}$ values of the same CAM sources on COLO-205, MCF-7, and ACHN cancer cells as given, previously in our published data, showed that these CAM therapies were significantly nontoxic to normal cells in contrast to 5-FU [28-30]. NRK-52E cells showed no change in their proliferation capacity on treatment with the various CAM extracts under study, when compared to 5-FU. This clearly indicates that 5-FU alters the growth kinetics of normal cells, while CAM therapy treated normal cells retain their normal proliferation, indicating no long time adverse effect on the cell cycle. The markers of apoptotic induction like chromatin condensation, membrane blebbing, and DNA laddering were seen by $\mathrm{AO} / \mathrm{EB}$ dual staining and DNA fragmentation assay, when cells were treated with 5FU; however, no signs of apoptosis were evident in NRK52E cells after treatment with CAM therapies. This study clearly indicates the effective role of CAM therapies over 5 -FU on normal kidney epithelial cells, NRK-52E cells, 


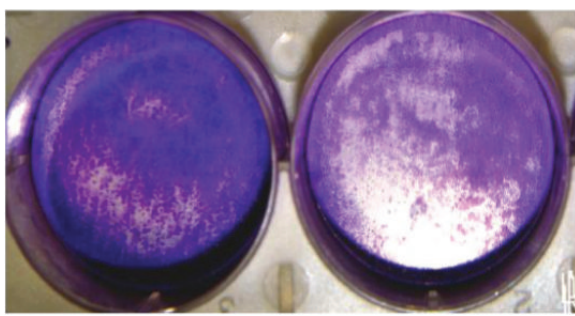

Control

HWE

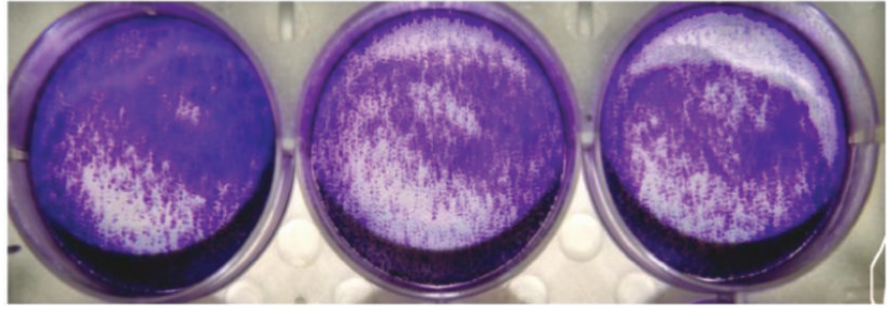

CWE

AWE

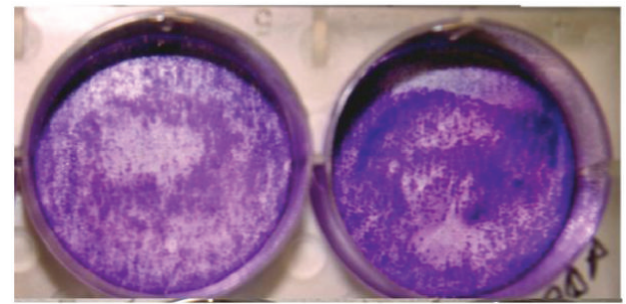

EAA

AAA

(a)

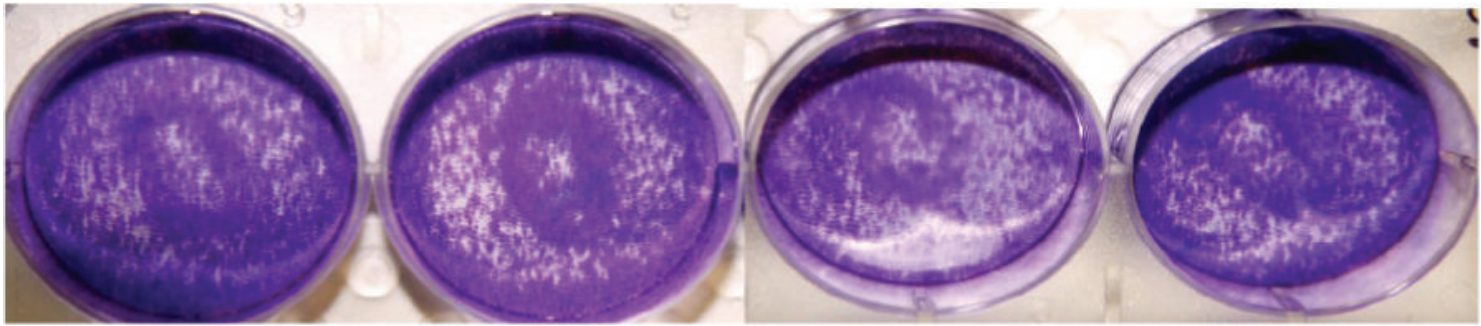

Control

PAE

AAE

MAE

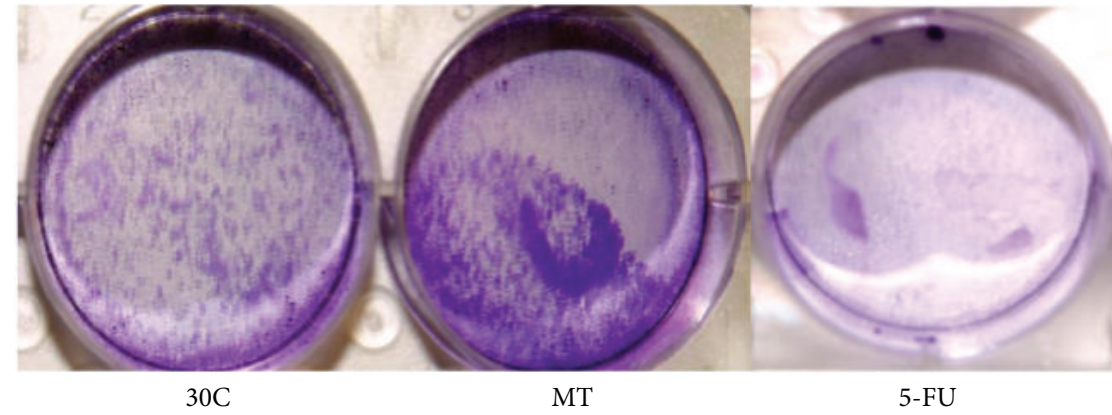

(b)

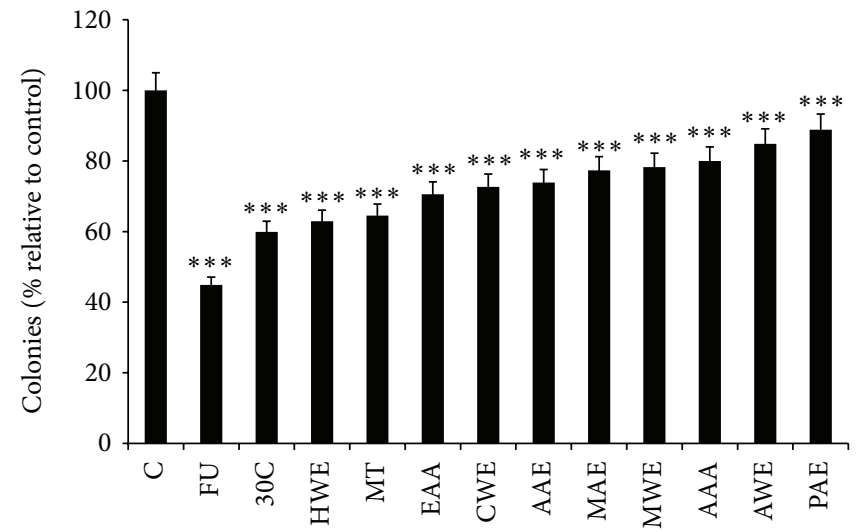

FIGURE 3: The pictographic representation of antiproliferative effect by colony formation assay of NRK-52E cells on treatment with $\mathrm{IC}_{50}$ values of (a) control (untreated), HWE, CWE, MWE, AWE, EAA, and AAA and (b) control (untreated), PAE, AAE, MAE, 30 C, and MT of Ruta and 5-FU for 14 days and (c) represents \% percent colonies formation wrt to control (untreated). 


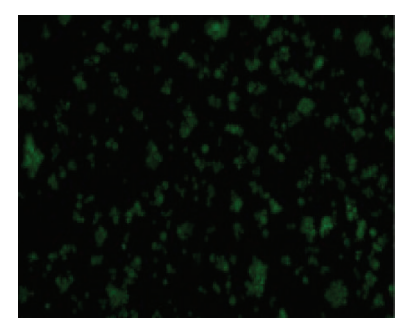

(A)

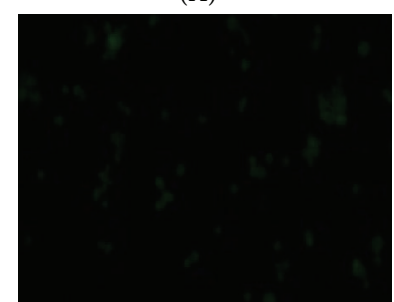

(E)

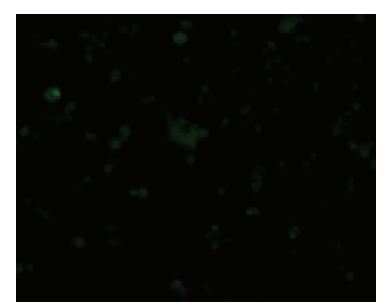

(I)

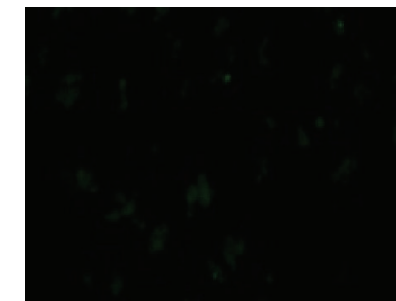

(M)

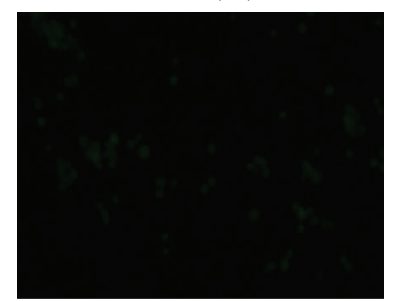

(Q)

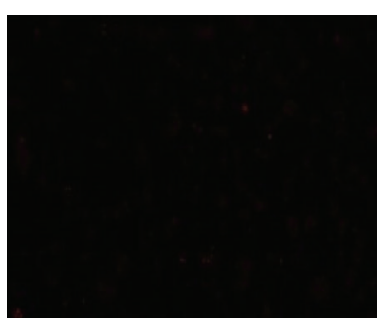

(B)

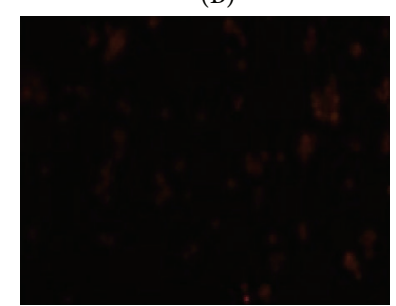

(F)

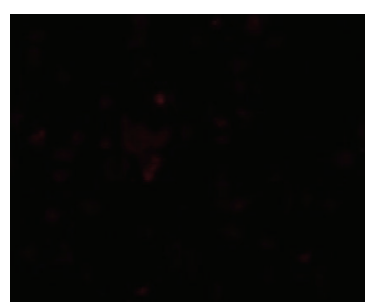

(J)

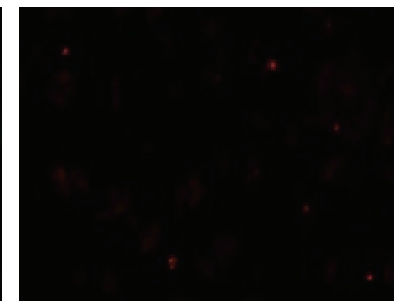

(N)

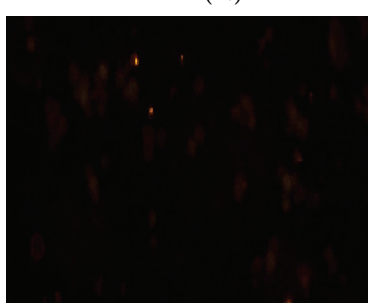

(R)

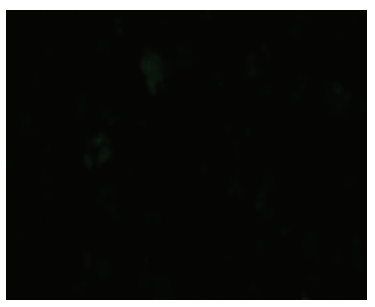

(U)

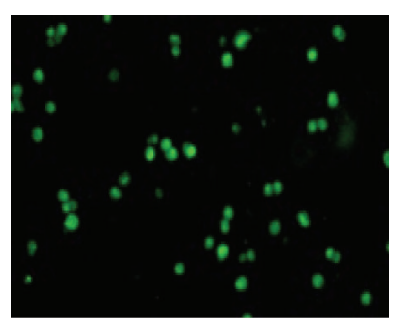

(C)

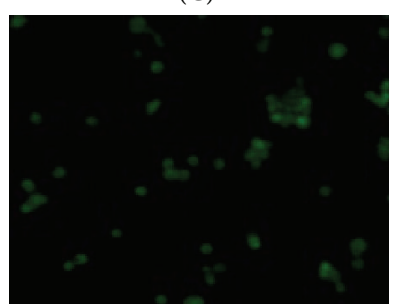

(G)

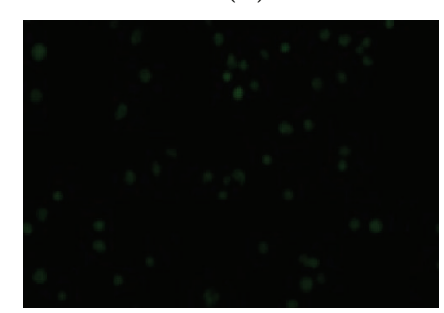

(K)

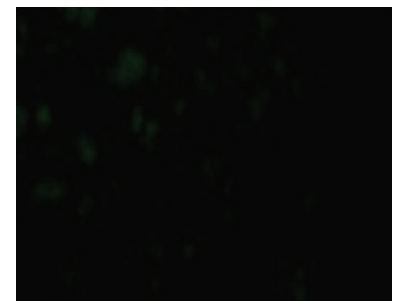

(O)

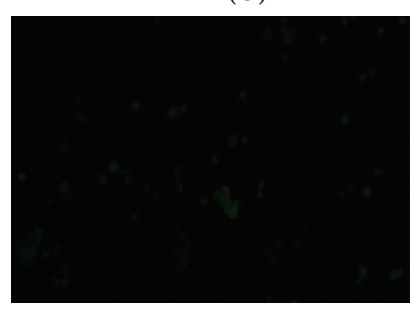

(S)

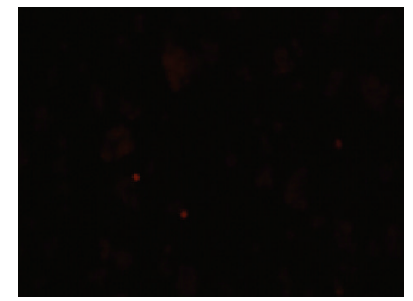

(V)

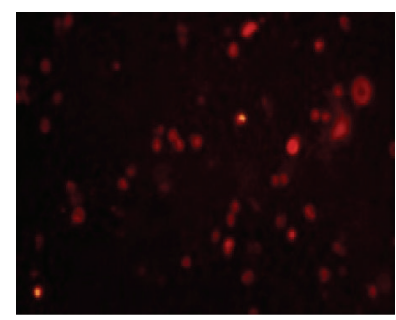

(D)

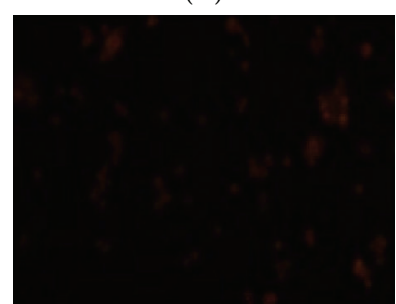

(H)

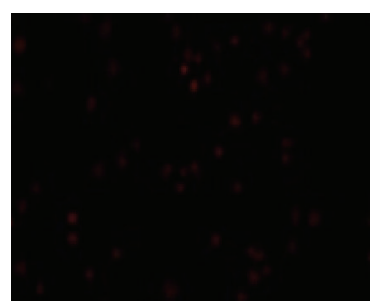

(L)

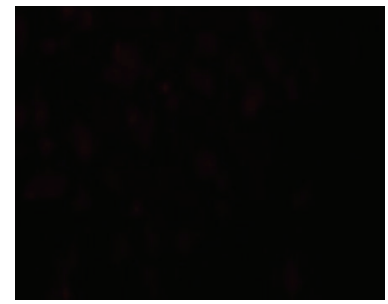

(P)

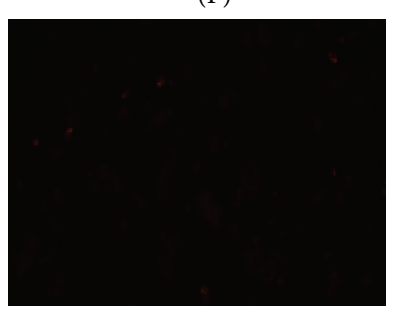

(T)

Figure 4: Continued. 


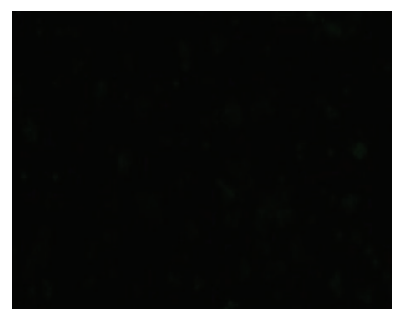

(W)

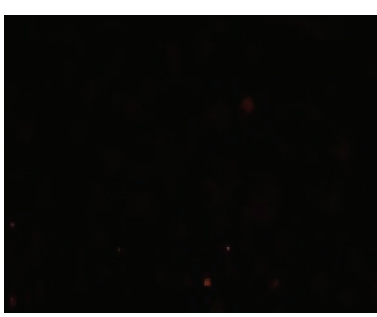

$(\mathrm{X})$

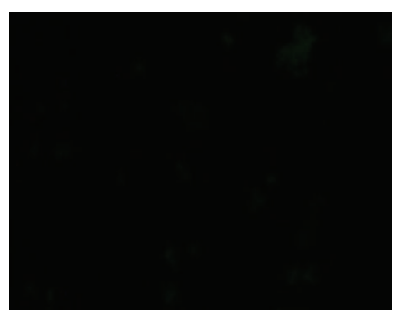

$(\mathrm{Y})$

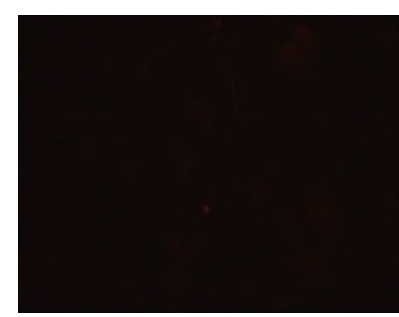

(Z)

FIgURE 4: Evaluation of apoptosis in NRK-52E cells by AO/EB staining after 48 hours of treatment with $\mathrm{IC}_{50}$ values of $\mathrm{HWE}$, CWE, MWE, AWE, EAA, AAA, PAE, AAE, MAE, $30 \mathrm{C}$, and MT of Ruta and 5-FU. Cells were observed under fluorescence microscope at 200x. (A) Control (untreated); (C) 5-FU; (E) HWE; (G) CWE; (I) MWE; (K) AWE; (M) EAA; (O) AAA; (Q) PAE; (S) AAE; (U) MAE; (W) 30 C; (Y) MT were observed under acridine orange filter and (B) control (untreated); (D) 5-FU; (F) HWE; (H) CWE; (J) MWE; (L) AWE; (N) EAA; (P) AAA; (R) PAE; (T) AAE; (V) MAE; (X) $30 \mathrm{C}$ (Z) MT were observed under ethidium bromide filter.

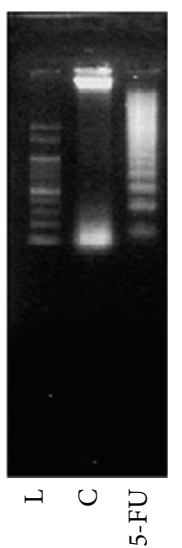

(a)

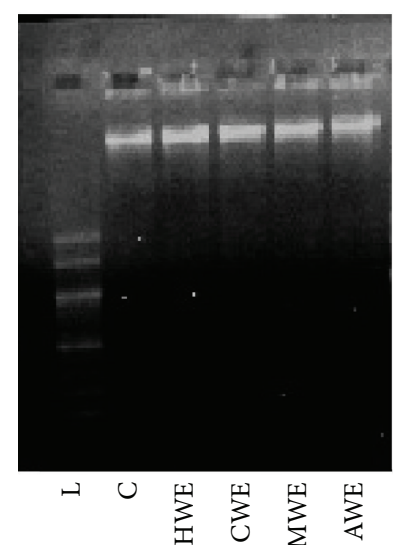

(b)

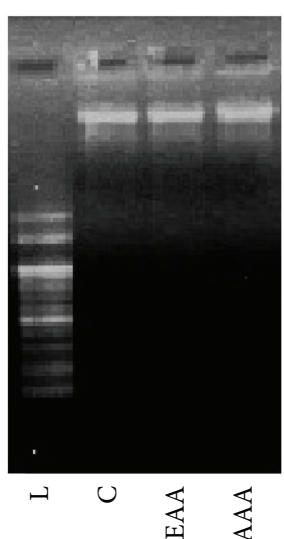

(c)

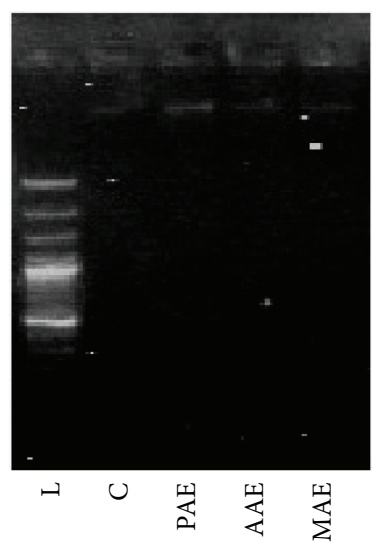

(d)

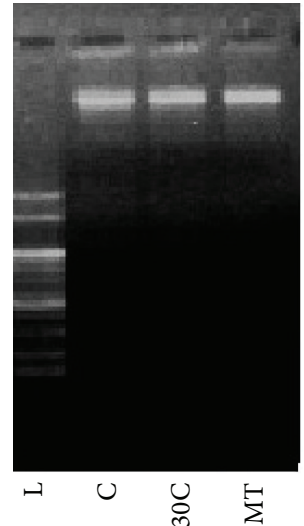

(e)

FIGURE 5: DNA fragmentation analysis in NRK-52 cells, after 48 hours of treatment with $\mathrm{IC}_{50}$ values of HWE, CWE, MWE, AWE, EAA, AAA, PAE, AAE, MAE, 30 C, and MT of Ruta and 5-FU. (a) L, C, 5-FU, (b) L, C, HWE, CWE, MWE, and AWE, (c) L, C, EAA, and AAA, (d) L, C, PAE, AAE, and MAE (E) L, C, 30 C, and MT. L-Ladder, C-untreated NRK-52E cells.

thereby verifying their nonside effect policy through scientific experimentation.

\section{Conclusion}

The efficacy of CAM therapies as an effective and alternative means to eradicate cancer cells without unduly harming normal cells is a very attractive option. The mechanism whereby it spares the normal cells while killing the cancer cells is as yet unknown. Though in this present study the noncytotoxic nature, by means of cell culture, as an in vitro model, has shown that the extracts selectively spare normal cells, further in vivo animal assays should be carried out to confirm the safeties of these CAM therapies.

\section{Conflict of Interests}

The authors declare that there is no conflict of interests regarding the publication of this paper.

\section{Acknowledgments}

The authors are extremely thankful to the Department of Biotechnology and Bioinformatics, Jaypee University of Information Technology, Solan, for providing the infrastructure for carrying out this work. They also wish to express their gratitude towards HAU (Chaudhary Charan Singh University, Hisar) and Directorate of Mushroom Research, Solan, India, for providing samples for their work.

\section{References}

[1] "Kidney cancer incidence and mortality worldwide in 2008: Globocan Cancer Fact Sheet," Globocan 2008, IARC, 2010.

[2] J. N. Yuan, Y. Chao, W. P. Lee et al., "Chemotherapy with etoposide, doxorubicin, cisplatin, 5-fluorouracil, and leucovorin for patients with advanced hepatocellular carcinoma," Medical Oncology, vol. 25, no. 2, pp. 201-206, 2008.

[3] C.-C. Lin, C. H. Hsu, C. Y. Huang et al., "Weekly cisplatin plus infusional high-dose 5-fluorouracil and leucovorin (P-HDFL) 
for metastatic urothelial carcinoma: an effective regimen with low toxicity," Cancer, vol. 106, no. 6, pp. 1269-1275, 2006.

[4] H. I. El-Sayyad, M. F. Ismail, F. M. Shalaby et al., "Histopathological effects of cisplatin, doxorubicin and 5-flurouracil (5FU) on the liver of male albino rats," International Journal of Biological Sciences, vol. 5, no. 5, pp. 466-473, 2009.

[5] L. Gao, R. Ma, J. Zhou, and S. Cheng, "Changes of serum erythropoietin during cisplatin- or 5-fluorouracil-induced anemia in rats," Toxicology Mechanisms and Methods, vol. 16, no. 9, pp. 501-506, 2006.

[6] J. Skretkowicz, M. Sekulska, M. Danilewicz, M. WagrowskaDanilewicz, and P. Polakowski, "Effect of some anticancer drugs and combined chemotherapy on renal toxicity," Biological Signals, vol. 5, no. 1, pp. 51-58, 1996.

[7] G. Bodeker and F. Kronenberg, "A public health agenda for traditional, complementary, and alternative medicine," The American Journal of Public Health, vol. 92, no. 10, pp. 1582-1591, 2002.

[8] A. Broom, K. R. Nayar, P. Tovey et al., "Indian cancer patients' use of Traditional, Complementary and Alternative Medicine (TCAM) and delays in presentation to hospital," Oman Medical Journal, vol. 24, no. 2, pp. 99-102, 2009.

[9] R. M. Bell, "A review of complementary and alternative medicine practices among cancer survivors," Clinical Journal of Oncology Nursing, vol. 14, no. 3, pp. 365-370, 2010.

[10] Y. H. Liu, M. L. Li, M. Y. Hsu et al., "Effects of a chinese herbal medicine, Guan-Jen-Huang (Aeginetia indica Linn.), on renal cancer cell growth and metastasis," Evidence-Based Complementary and Alternative Medicine, vol. 2012, Article ID 935860, 10 pages, 2012.

[11] WHO, Diet, Nutrition and the Prevention of Chronic Diseases, Technical Report Series, no. 916, World Health Organization, Geneva, Switzerland, 2003.

[12] P. Chaturvedi, U. Chaturvedi, and B. Sanyal, "Alternative medicine and cancer patients in less developed countries," The Lancet Oncology, vol. 3, no. 1, p. 10, 2002.

[13] S. K. Pai, "Use of alternative cancer medicine in India," The Lancet Oncology, vol. 3, no. 7, pp. 394-395, 2002.

[14] S. Rana, J. K. Kamboj, and V. Gandhi, "Living life the natural way-wheatgrass and health," Functional Foods in Health and Disease, vol. 1, no. 11, pp. 444-456, 2011.

[15] A. Dey, "Achyranthes aspera L: phytochemical and pharmacological aspects," International Journal of Pharmaceutical Sciences Review and Research, vol. 9, no. 2, pp. 72-82, 2011.

[16] G. H. Beulah, A. A. Margret, and J. Nelson, "Marvelous medicinal mushrooms," International Journal of Pharma and Bio Sciences, vol. 3, no. 1, pp. 611-6115, 2013.

[17] J. Asgarpanah and R. Khoshkam, "Phytochemistry and pharmacological properties of Ruta graveolens L.," Journal of Medicinal Plants Research, vol. 6, no. 23, pp. 3942-3949, 2012.

[18] C. N. Lai, "Chlorophyll: the active factor in wheat sprout extracts inhibiting the metabolic activation of carcinogens in vitro," Nutrition and Cancer, vol. 1, pp. 19-21, 1979.

[19] C. N. Lai, B. J. Dabney, and C. R. Shaw, "Inhibition of in vitro metabolic activation of carcinogens by wheat sprout extracts," Nutrition and Cancer, vol. 1, pp. 27-30, 1978.

[20] G. Falcioni, D. Fedeli, L. Tiano et al., "Antioxidant activity of wheat sprouts extract in vitro: inhibition of DNA oxidative damage," Journal of Food Science, vol. 67, no. 8, pp. 2918-2922, 2002.
[21] J. W. Fahey, K. K. Stephenson, A. T. Dinkova-Kostova, P. A. Egner, T. W. Kensler, and P. Talalay, "Chlorophyll, chlorophyllin and related tetrapyrroles are significant inducers of mammalian phase 2 cytoprotective genes," Carcinogenesis, vol. 26, no. 7, pp. 1247-1255, 2005.

[22] B. Peryt, T. Szymczyk, and P. Lesca, "Mechanism of antimutagenicity of wheat sprout extracts," Mutation Research, vol. 269, no. 2, pp. 201-215, 1992.

[23] S. Padalia, S. Drabu, I. Raheja, A. Gupta, and M. Dhamija, "Multitude potential of wheatgrass juice (Green Blood)," An Overview, Chronicles of Young Scientists, vol. 1, no. 2, pp. 23-228, 2010.

[24] S. Edwin, E. E. Jarald, L. Deb et al., "Wound healing and antioxidant activity of Achyranthes aspera," Pharmaceutical Biology, vol. 46, no. 12, pp. 824-828, 2008.

[25] R. Y. Vasudeva, G. R. Duddukuri, B. G. Sunil, and R. R. Athota, "Immunomodulatory activity of Achyranthes aspera on the elicitation of antigen-specific murine antibody response," Pharmaceutical Biology, vol. 40, no. 3, pp. 175-178, 2002.

[26] I. C. F. R. Ferreira, L. Barros, and R. M. V. Abreu, "Antioxidants in wild mushrooms," Current Medicinal Chemistry, vol. 16, no. 12, pp. 1543-1560, 2009.

[27] P. H. K. Ngai and T. B. Ng, "A mushroom (Ganoderma capense) lectin with spectacular thermostability, potent mitogenic activity on splenocytes, and antiproliferative activity toward tumor cells," Biochemical and Biophysical Research Communications, vol. 314, no. 4, pp. 988-993, 2004.

[28] S. Pathak, A. S. Multani, P. Banerji, and P. Banerji, "Ruta 6 selectively induces cell death in brain cancer cells but proliferation in normal peripheral blood lymphocytes: a novel treatment for human brain cancer," International Journal of Oncology, vol. 23, no. 4, pp. 975-982, 2003.

[29] M. Ratheesh and A. Helen, "Anti-inflammatory activity of Ruta graveolens Linn on carrageenan induced paw edema in wistar male rats," African Journal of Biotechnology, vol. 6, no. 10, pp. 1209-1211, 2007.

[30] S. Tandon, A. Arora, S. Singh, J. Monga, and S. Arora, "Antioxidant profiling of Triticum aestivum (wheatgrass) and its antiproliferative activity in MCF-7 breast cancer cell line," Journal of Pharmacy Research, vol. 4, no. 12, pp. 4601-4604, 2011.

[31] S. Arora, S. Goyal, J. Balani, and S. Tandon, "Enhanced antiproliferative effects of aqueous extracts of some medicinal mushrooms on colon cancer cells," International Journal of Medicinal Mushrooms, vol. 15, no. 3, pp. 301-314, 2013.

[32] S. Arora, A. Aggarwal, P. Singhla, S. Jyoti, and S. Tandon, "Antiproliferative effects of homeopathic drugs on human kidney, colon and breast cancer cells," Homeopathy, vol. 102, pp. 274-282, 2013.

[33] S. D. Kulkarni, J. C. Tilak, R. Acharya, N. S. Rajurkar, T. P. A. Devasagayam, and A. V. R. Reddy, "Evaluation of the antioxidant activity of wheatgrass (Triticum aestivum L.) as a function of growth under different conditions," Phytotherapy Research, vol. 20, no. 3, pp. 218-227, 2006.

[34] M. H. Roudkenar, R. Halabian, A. M. Roushandeh et al., "Lipocalin 2 regulation by thermal stresses: protective role of Lcn2/NGAL against cold and heat stresses," Experimental Cell Research, vol. 315, no. 18, pp. 3140-3151, 2009.

[35] K. Phromnoi, S. Reuter, B. Sung, P. Limtrakul, and B. B. Aggarwal, "A dihydroxy-pentamethoxyflavone from Gardenia obtusifolia suppresses proliferation and promotes apoptosis of tumor cells through modulation of multiple cell signaling 
pathways," Anticancer Research, vol. 30, no. 9, pp. 3599-3610, 2010.

[36] D. Ribble, N. B. Goldstein, D. A. Norris, and Y. G. Shellman, "A simple technique for quantifying apoptosis in 96-well plates," BMC Biotechnology, vol. 5, article 12, 2005.

[37] P. Bossù, "Qualitative analysis of DNA fragmentation by agarose gel electrophoresis," http://www.cyto.purdue.edu/archive/ flowcyt/research/cytotech/apopto/data/chap4.htm.

[38] R. Han, Y. M. Yang, J. Dietrich, A. Luebke, M. Mayer-Pröschel, and M. Noble, "Systemic 5-fluorouracil treatment causes a syndrome of delayed myelin destruction in the central nervous system," Journal of Biology, vol. 7, no. 4, p. 12, 2008.

[39] E. Nora and H. M. Ali, "Protective effect of captopril against 5fluorouracil-induced hepato and nephrotoxicity in male albino rats," Journal of American Science, vol. 8, no. 2, 2012. 


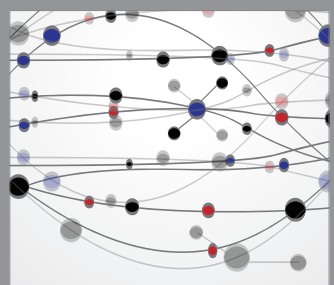

The Scientific World Journal
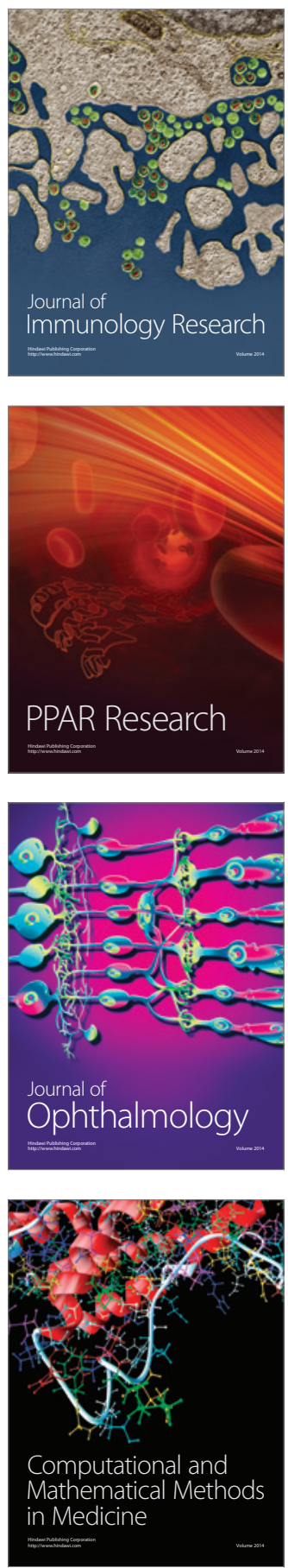

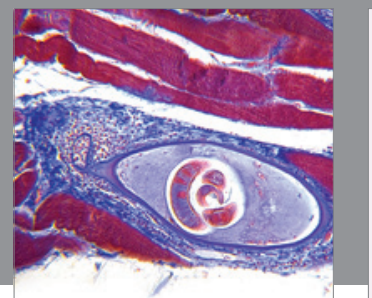

Gastroenterology

Research and Practice
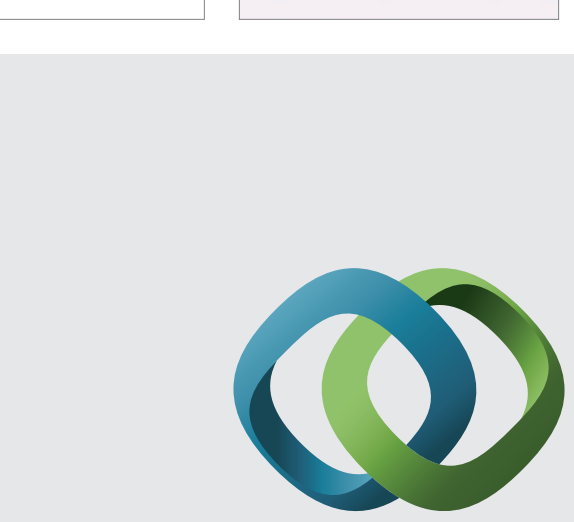

\section{Hindawi}

Submit your manuscripts at

http://www.hindawi.com
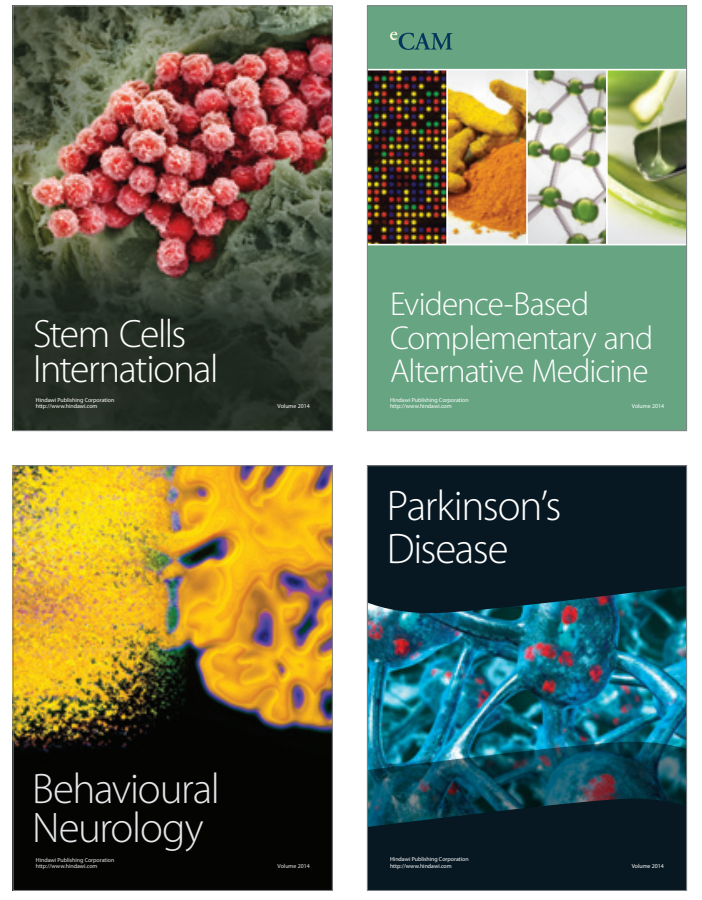
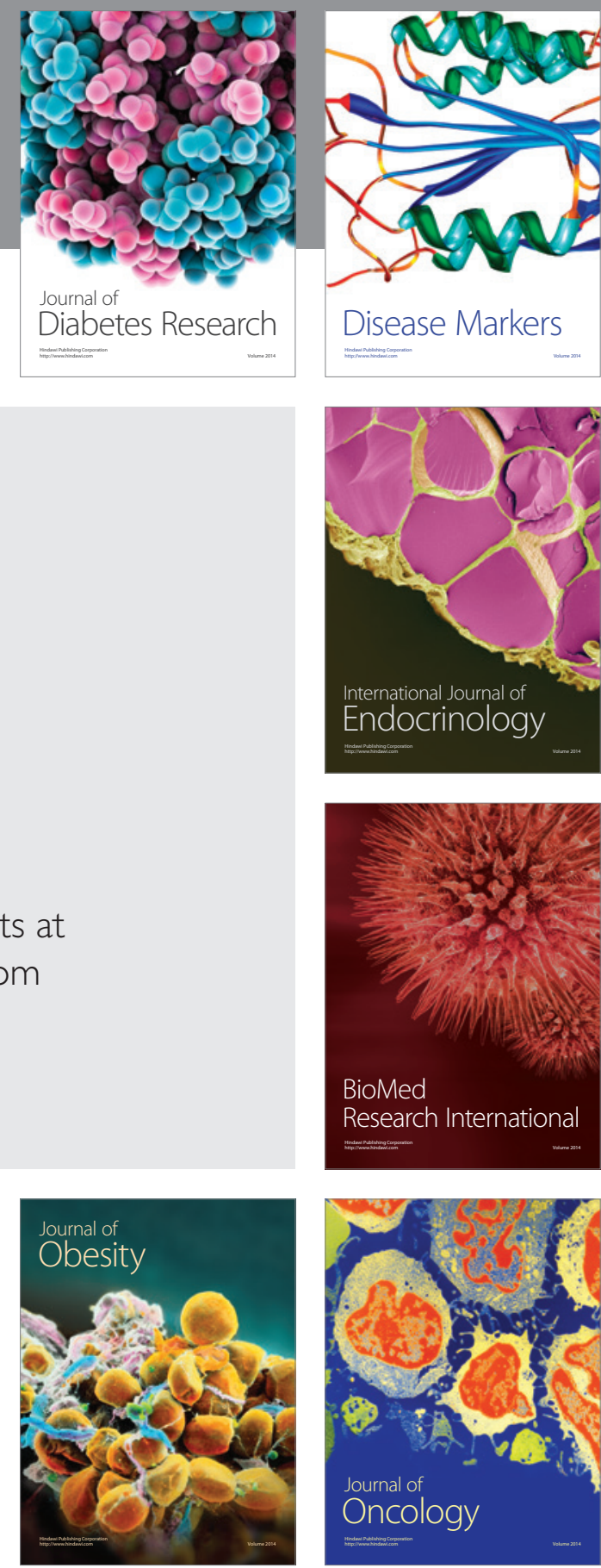

Disease Markers
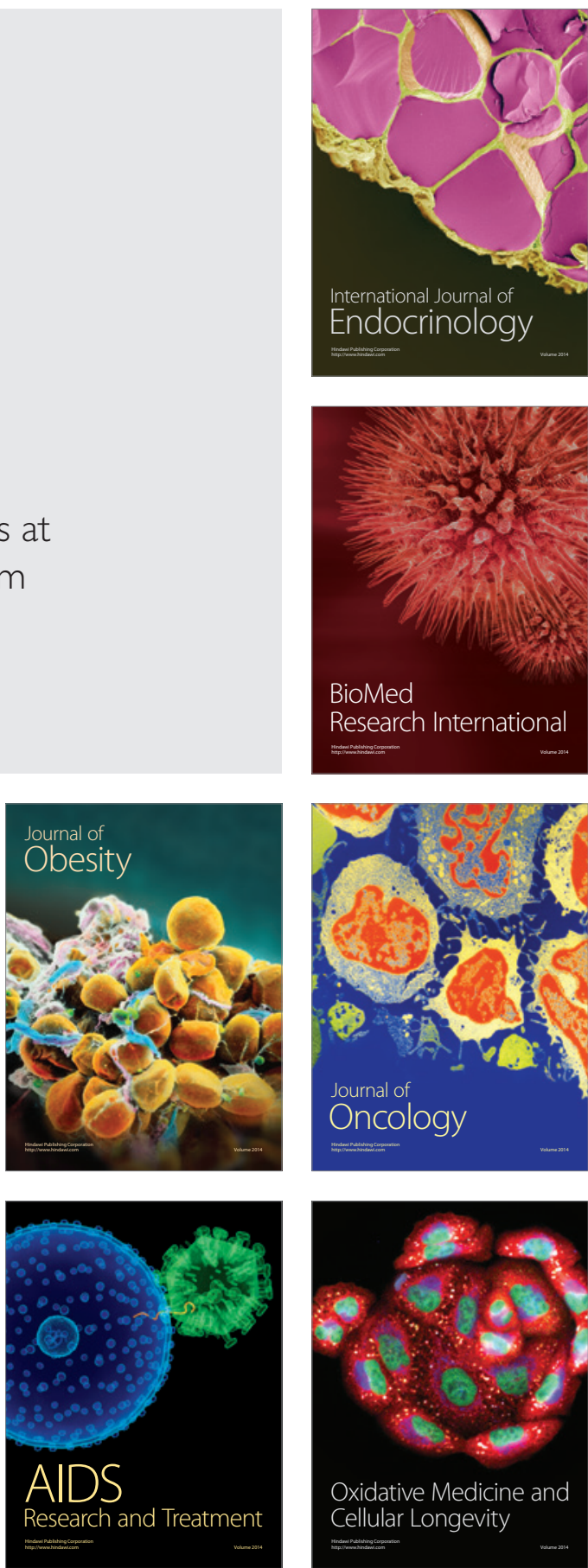